\title{
Ana Cristina Cesar, Paulo Henriques Britto e o legado de João Cabral
}

\author{
Ana Cristina Cesar, Paulo Henriques Britto and \\ João Cabral's legacy
}

Eduardo Horta Nassif Veras ${ }^{1}$

RESUMO

O artigo apresenta uma discussão sobre a apropriação crítica do legado de João Cabral de Melo Neto pelas poéticas de Ana Cristina Cesar e Paulo Henriques Britto. A análise recai especialmente sobre os modos de reconfiguração do eu lírico, a concepção de composição e o problema da comunicação nas obras em questão. O reinvestimento no corpo é tomado, finalmente, como elemento privilegiado para se pensar o lugar da subjetividade nos dois projetos literários e sua relação com a herança cabralina.

Palavras-chave: João Cabral; Poesia contemporânea; Teoria do sujeito lírico.

ABSTRACT

The article presents a discussion about the critical appropriation of João Cabral de Melo Neto's legacy by the poetics of Ana Cristina Cesar and Paulo Henriques Britto. The analysis focuses on reconfiguring the lyrical subject, the conception of composition, and the communication problems in the works in question. Reinvestment in the body is finally taken as a privileged element to think about the place of subjectivity in both literary projects and their relationship with Cabral's heritage.

Keywords: João Cabral; Contemporary Poetry; Lyric Subject Theory.

1 Universidade Federal do Triângulo Mineiro, Uberaba, Minas Gerais. E-mail: eduardohnveras@ gmail.com 
$\mathrm{J}$

á se disse repetidas vezes que a poesia de João Cabral de Melo Neto e, em especial, uma determinada narrativa que o poeta ajudou a construir sobre ela e sobre si mesmo, e que a Crítica tratou muitas vezes de amplificar, desempenham um papel de relevância na constituição de diversos projetos poéticos contemporâneos. Uma possível narrativa da poesia brasileira dos últimos quarenta anos poderia ter como impulso a ideia de uma "relação tensa com a poética de Cabral" (SISCAR, 2018, p. 610). Antes de examinar as respostas que dois poetas da passagem dos anos 70 para os anos 80 dão aos problemas colocados pela poética de Cabral, é preciso dizer que esta não exclui necessariamente as narrativas crítico-biográficas que se construíram ao seu redor. Leonardo Gandolfi (2010, p. 171) observa que Cabral:

talvez seja um dos poetas brasileiros que mais controlou as narrativas sobre sua vida. Sobretudo em entrevistas e até mesmo em poemas, enumerou biografemas que, diferentemente do que se supõe num primeiro olhar, acabam por participar da leitura de sua poesia. 
Apesar dos esforços louváveis e necessários que a Crítica principalmente universitária - tem feito para desconstruir o lugar-comum do poeta duro, antilírico, negador da subjetividade e da música ${ }^{2}$, é preciso compreender que as respostas que a poesia contemporânea brasileira dá ao legado de João Cabral não estão imunes ao discurso algo mitificante que se construiu ao redor do poeta "áspero".

Penso que o período que se descortina na passagem para os anos oitenta é um espaço privilegiado para se pensar a recepção de Cabral e suas consequências para o futuro da poesia brasileira, também em função daquela narrativa que, mesmo que questionável, tornou-se um operador de leitura e recepção da obra. A julgar pelo diagnóstico de Haroldo de Campos (1997), que, em 1984, anuncia o fim da era utópica das vanguardas, o período que se inicia se caracterizará pela multiplicidade de respostas à tradição - especialmente da poesia brasileira do século XX, intensamente marcada pelos movimentos de vanguarda, alguns dos quais reivindicando a herança cabralina. A tentativa de compreensão crítica da poesia daquele período, como mostra Marcos Siscar (2010, p. 152), está marcada por um mal-estar teórico que "corresponde [à] sensação vivida pelos próprios poetas de estarem presos em uma espécie de impasse”, pois se mostram incapazes, como explica o crítico na sequência, de se posicionarem claramente diante da oposição entre a poesia formalista e a poesia da experiência herdada do período anterior. Essa oposição atravessa toda a tradição da poesia moderna e é indissociável da desconfiança que poetas como Edgar Poe, Baudelaire e Mallarmé, cada um à sua maneira, expressaram em relação à poesia do eu, isto é, à ideia romântica da poesia como canal de expressão da subjetividade privada. Para não me estender demais, contento-me em relembrar o conceito de "despersonalização", que Hugo Friedrich (1978, p. 36) posicionou no centro de sua interpretação da tradição moderna: "Com Baudelaire começa a despersonalização da lírica moderna, pelo menos no sentido que a palavra lírica já não nasce da unidade de poesia e pessoa empírica (...)”. O problema tem rebatimentos intensos, ainda que específicos, na poesia brasileira do século XX, como bem mostrou Luiz Costa Lima (1995), e atravessa o âmago da reflexão de e a partir de Cabral sobre a poesia.

No ensaio "Poesia e composição", conferência pronunciada na Biblioteca de São Paulo, em 1952, Cabral (1994, p. 725) reelabora aquela

2 A recusa da música é um dos clichés mais repisados na recepção, digamos, escolar de João Cabral de Melo Neto. Se há uma recusa, em sua obra, da melodia cantabile, da música como expressão das emoções, por outro lado é preciso reconhecer nela o interesse pela dimensão rítmica, pela exploração do som em sua concretude. Arriscaria dizer que a "música" de Cabral, ao se realizar como crítica do pathos musical, opõe-se à tradição romântica, mas poderia ser aproximada do amplo movimento que, na passagem do século XIX para o XX, colocou em xeque o sistema tonal, fundado sobre a relação entre a linguagem musical, o discurso e os afetos. Para um bom apanhado crítico da recusa da expressividade em compositores do período, cf. JANKÉLÉVTCH, Vladimir. A música e o inefável. Trad. Clóvis Salgado Gontijo. São Paulo: Perspectiva, 2018. 
E. H. N. VERAS Ana Cristina Cesar, Paulo Henriques Britto e o legado de João Cabral oposição nos termos de uma oscilação entre duas maneiras de compor: "A composição literária oscila permanentemente entre dois polos extremos a que é possível levar as ideias de inspiração e trabalho da arte". A maneira como o poeta-ensaísta coloca o problema desvela as nuances da oposição poesia do eu versus poesia da forma, que tende não raro a simplificações enganosas. Em Cabral, o foco recai em três pontos complementares, a saber: 1) a constituição do sujeito no ou pelo poema, isto é, a maneira como o eu empírico se expressa ou se (des)constrói na ou pela linguagem, 2) a diferença entre trabalho e espontaneidade, em outras palavras, entre a composição meditada e a poesia como resíduo impensado da experiência pessoal e, por fim, 3) as implicações de tudo isso sobre o problema da comunicação, da tarefa pública do poeta. A desconfiança de Cabral em relação à poesia espontânea parece ter menos a ver com uma simples adesão à tradição moderna do antilirismo que com um projeto de reconfiguração do sujeito lírico em sua relação com o real, com a própria poesia e com a coletividade. Resumindo o problema para os fins deste artigo, trata-se de entender como a relação de Cabral com os tópicos negativos da tradição da lírica moderna - nos termos de Friedrich, "obscuridade", "hermetismo", "despersonalização", "desrealização" etc - se reconfigura criticamente em função de um projeto que tem o problema da inserção do poeta no espaço público, sua capacidade de atingir o leitor, como eixo norteador. Isso explica o desejo de controle composicional, inseparável do controle da subjetividade, que passa a ser pensada como uma construção realizada no plano das relações da linguagem com o mundo. Isso explica também a associação do acaso, aquela dimensão da vida e da própria poesia que escapa ao controle da razão, a elementos musicais e orgânicos, por exemplo na "Fábula de Anfion", em franca oposição ao caráter idealmente mineral da linguagem objetiva, leia-se, da linguagem destinada à superação das idiossincrasias subjetivas em nome de uma ética da comunicação. Nesse sentido, entendo um livro como Psicologia da composição, impregnado, desde o título, pelas questões que venho levantando, como uma reflexão poética sobre o ideal da poesia, não exatamente antilírica tout court, mas como língua compartilhável, isto é, como língua que transcende o universo difuso e algo incomunicável da subjetividade privada. Se o poeta "Sai de [seu] poema / como quem lava as mãos" (CABRAL DE MELO NETO, 1994, p. 93) é para nele se inscrever de forma transfigurada, capaz de se oferecer como objeto partilhável. Assim, Cabral se afasta claramente da tradição algo mística da poesia pura para recolocar o problema da referência (mimética e expressiva) no âmbito daquilo que Marcos Siscar nomeia, repetidas vezes, "drama da destinação”. É em função desse drama, parece-me, que Cabral propõe não exatamente o apagamento mas uma reconfiguração do sujeito lírico na direção do outro, do mundo exterior, da linguagem, para realizar-se "a si mesmo como um outro", conforme escreve Michel Collot (2018, p. 52), lembrando a
Revista Letras,

Curitiba, UFPR, n. 102, pp. 152-170, jul./dez. 2020 ISSN 2236-0999 (versão eletrônica) 
bela fórmula de Paul Ricœur, e conforme descreve Leonardo Gandolfi (2010, p. 174) quando chama a atenção para o gesto cabralino de projeção do "eulírico na paisagem, realizando um duplo processo de dar inveja a Fernando Pessoa", ao "objetiviza[r] o sujeito e "subjetiviza[r] o objeto".

\section{Breve digressão teórica}

Pretendo mostrar como o problema da destinação em Cabral repercute na obra de dois poetas que se inserem no início da era que Haroldo de Campos (1997) classifica como pós-utópica: Ana Cristina Cesar e Paulo Henriques Britto. Meu objetivo será mostrar como os dois poetas participam da reconfiguração do sujeito proposta na poética de Cabral, estabelecendo com ela uma relação tensa, marcada por um duplo gesto de adesão e reelaboração das questões que procurei apresentar superficialmente acima.

Permito-me uma última digressão antes de adentrar o universo dos dois poetas para esboçar muito brevemente uma conversa com dois teóricos que têm discutido amplamente nos últimos anos a questão do sujeito lírico e do lirismo. Da vasta contribuição crítica de Michel Collot para esse debate, destaco apenas seu empenho em mostrar que o sujeito é modernamente reavaliado "não mais (...) em termos de substância, de interioridade, mas em sua relação constitutiva com um exterior que o altera” (COLLOT, 2018, p. 52). Essa desconstrução do conceito de eu lírico enclausurado na interioridade do sujeito leva Michel Collot a identificar no lirismo contemporâneo um espaço liminar traçado entre o controle do sujeito e sua penetração pelo real, fronteira que me permitirei traduzir também nos termos opostos do trabalho poético e da inspiração, caros à reflexão de Cabral em "Poesia e composição", e que terão impacto direto sobre as respostas que Ana Cristina Cesar e Paulo Henriques Britto, como veremos, dão à poética cabralina. De volta ao crítico francês, interessa-me sobretudo sua noção de "sujeito fora de si" e a afirmação de que a constituição do eu se dá pelo atravessamento do outro - esteja este identificado ao real, ao mundo, ao leitor, ou à própria linguagem. Seja como for, Collot (2018, p. 51) entende que "o sujeito não pode se exprimir senão por essa carne sutil que é a linguagem, que dá corpo ao seu pensamento, mas que permanece um corpo estranho". Minha hipótese é que a poética de Cabral, antes mesmo da teorização realizada em obras como a de Collot, delineia esse espaço movente - composto pelas figuras do sujeito em suas relações com o real, o leitor e a linguagem - no qual o drama de alguma poesia contemporânea brasileira se materializará. Compreender como cada poeta move as linhas fronteiriças desse espaço me perece um caminho profícuo para abordar criticamente nosso presente.

Jean-Michel Maulpoix, outro teórico francês que tem se dedicado a repensar o lirismo em geral, ressalta mais uma vez o caráter exterior e 
E. H. N. VERAS Ana Cristina Cesar, Paulo Henriques Britto e o legado de João Cabral liminar do sujeito poético moderno, que ele define como "a quarta pessoa do singular", isto é, uma voz enunciativa que não se confunde com as vozes gramaticais do discurso. Para Maulpoix (1998, p. 32), o sujeito lírico "se instala no intervalo entre o indivíduo e o conteúdo de sua vida afetiva, entre o que a criatura quer e aquilo de que é feita". Em resumo, Maulpoix, na esteira de Collot, mostra que o outro que atravessa o sujeito lírico pode estar nele próprio compreendido. Isso nos leva de volta ao drama anfiônico-cabralino do controle da subjetividade e do discurso, pois é antes de tudo contra o que há de difuso em si mesmo que o poeta da composição se levanta. A crítica ao sujeito substancial dotado de interioridade abre espaço a uma visão do sujeito lírico como potencial figurativo, "um 'eu' em potência”, escreve Maulpoix (1998, p.34). As possibilidades de reconfiguração daquele sujeito, consideradas suas múltiplas relações consigo mesmo, com o real, com o outro, a tradição poética, a linguagem etc., são praticamente infinitas. Tentarei mostrar a seguir como o sujeito poético se constrói e se comporta nas obras de Ana Cristina Cesar e Paulo Henriques Britto, mantendo sempre em perspectiva o legado de João Cabral de Melo Neto.

\section{O corpo do poema}

A conhecida afirmação feita por Ana C. (2016, p. 185) em junho de 1976 de que a poesia de sua geração seria "anticabralina por excelência" não deve desencorajar uma reflexão sobre os pontos de contato e inflexão da poeta carioca com o legado de João Cabral. Há certamente em sua obra um discurso de valorização da experiência, do corpo, do desejo, em detrimento da poesia voltada para si mesma. "Estou farto da materialidade do signo / da metalinguagem narcísica dos poetas / do texto de espelho em punho revirando os óculos / modernos" (CESAR, 2013, p. 325), diz um poema de outubro de 1975. Ana Cristina Cesar estabelece aqui, contra uma poesia semiótica, narcisicamente ${ }^{3}$ voltada para si mesma, um claro diálogo com Manuel Bandeira (1993, p.129), cujo poema "Poética", de Libertinagem, é explicitamente evocado, desde o primeiro verso: "Estou farto.... Como para Bandeira, um determinado tipo de poesia, perfeitamente identificável do ponto de vista histórico, é aqui posto em xeque. Em " $33^{\mathrm{a}}$ poética", contudo, o alvo não é mais o "lirismo comedido" e "bem comportado" (BANDEIRA, 1993, p. 129), mas o discurso metapoético da linhagem mestre da poesia

\footnotetext{
3 A crítica ao "narcisismo" das poéticas de cunho formalista feita por Ana Cristina Cesar parece antecipar afirmações como esta de Michel Collot (2018, p. 77): "Nada de mais narcísico, sob alguns aspectos, do que o antilirismo contemporâneo, no qual o sujeito se compraz, às vezes, no deleite melancólico, não parando de contemplar sua própria deserção no espelho de uma escrita que não cessa de voltar para si mesma."
}

Revista Letras,

Curitiba, UFPR, n. 102, pp. 152-170, jul./dez. 2020 ISSN 2236-0999 (versão eletrônica) 
moderna, bem representada entre nós pelos poetas concretos, em grande medida devedores, como se sabe, do legado cabralino.

\author{
estou farta dessa fala enxuta \\ dessa ausência de objetos rotundos e contundentes \\ do conluio entre cifras e cifrantes \\ da feminil hora quieta da palavra \\ da lista (política raquítica sifilítica) de supersignos cabais: "duro \\ ofício", "espaço em branco", "vocábulo delirante", "traço infinito"
}

(CESAR, 2013, p. 325).

Interessante observar a mudança de gênero na segunda estrofe do poema. No início, a poeta diz "Estou farto", uma maneira de afirmar a proximidade com o gesto de ruptura realizado por Bandeira. Já na segunda estrofe, a mesma expressão se conjuga no feminino: "estou farta", produzindo um ponto de inflexão no diálogo com o poema modernista. Nem sinal da palavra "lirismo" no poema de Ana C., a ela interessa mais, sem necessariamente se opor às reivindicações bandeirianas, levantar-se contra o vocabulário predominantemente técnico, formalista, semiótico e metalinguístico da poesia de vanguarda, para em seguida reivindicar uma poesia que se abre para a subjetividade, para o corpo, para o desejo, sem, contudo, abrir mão de um trabalho com o signo. Na poesia de Ana C., a reconsideração da subjetividade não se dá pela via de uma relação ingênua com a linguagem, mas depende diretamente de uma manipulação cuidadosa, por exemplo, do léxico e da sintaxe:

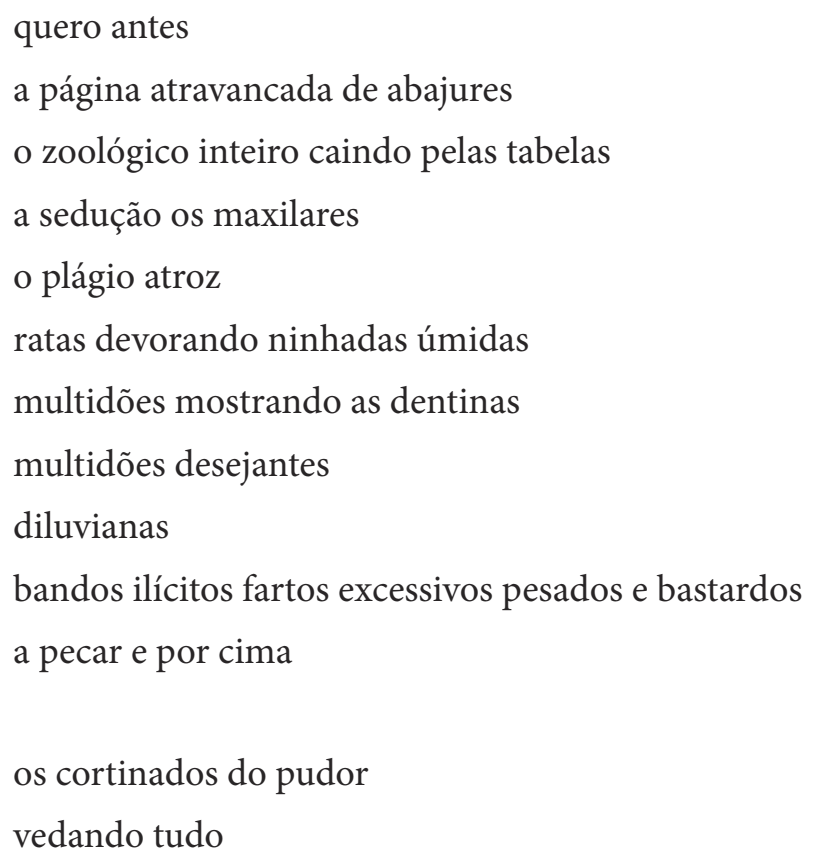


E. H. N. VERAS

Ana Cristina Cesar,

Paulo Henriques

Britto e o legado de João Cabral om goma

de mascar.

(CESAR, 2013, p. 325).

" $33^{a}$ poética" exemplifica com perfeição o espaço ambivalente que a poética de Ana Cristina Cesar traça na geografia de poesia brasileira de seu tempo, marcada pela rivalidade entre experiência e formalismo, conforme descreve Marcos Siscar (2010, p. 152). Perceba-se que o poema não abre mão de pensar a poesia, ao contrário, a poeta reivindica outra "página" que não a "página em branco" da tradição mallarmeana, uma página onde pululam corpos, humanos e animais, multidões atravessadas pelo desejo, pelo deboche e pelo pecado. Em oposição à pureza do signo vazio e racionalmente controlado, aqui irrompem, tanto no plano das referências quanto no plano do registro do próprio poema, as mais diversas manifestações do acaso. $\mathrm{O}$ mais interessante, contudo, é que, em Ana Cristina Cesar, nada disso desagua numa negação da construção poética, e é justamente nesse ponto que a aparente ruptura com a poética de João Cabral se mostra questionável.

" $33^{a}$ poética" termina com uma clara referência ao fingimento poético. Toda a horda de corpos desejantes e desviantes que irrompe no poema vem a público sob os "cortinados do pudor", isto é, dissimulados por um discurso construído para velar minimamente o obsceno. Interessa sobretudo perceber que a dimensão do jogo é enfatizada pela poeta, que não hesita em dizer que o tal cortinado veda tudo "com goma de mascar"; em outras palavras, fica claro o quanto esse gesto se projeta também precário e debochado.

Isso porque a reconsideração da subjetividade em Ana C. não coincide com o retorno à expressão pessoal simplesmente. Ela se dá, ao contrário, como afirmação de uma subjetividade inscrita na própria linguagem e na relação com o outro, um pouco na direção daquilo que afirma Michel Collot (2018, p. 51). Em outras palavras, o sujeito poético ali se configura como promessa ofertada ao leitor nesse jogo de velamento e desvelamento de uma intimidade teatralizada (CESAR, 2013, p. 119). Trata-se, em suma, de reinvestir no impasse, na tensão entre o eu e o poema, a espontaneidade e a composição. Em uma intervenção da poeta no âmbito de um curso ministrado pela professora Beatriz Resende, em de 6 abril de 1983, Ana C. afirma que "a subjetividade, o íntimo, o que a gente chama de subjetividade não se coloca na literatura. É como se o eu estivesse brincando, jogando com essa tensão, com essa barreira" (CESAR, 2016, p. 296). Esse jogo sobre o qual fala a poeta nos convida a pensar o problema da destinação e o papel central que o leitor assume na construção do sentido e na composição de uma imagem a posteriori desse sujeito que fala no poema. A teus pés, livro de 1982, é, desde o título, uma prova cabal de que a relação com o outro assume importância central na poética de Ana C. Já no primeiro poema, sem título, da coletânea, Ana C. revisita e reelabora algumas

Revista Letras,

Curitiba, UFPR, n. 102, pp. 152-170, jul./dez. 2020 ISSN 2236-0999 (versão eletrônica) 
das principais figuras do legado de João Cabral sobre as quais discorri no início deste artigo. O poema apresenta modulações em torno do tópico do controle: "Eu tenho uma ideia. / Eu não tenho a menor ideia."; do tópico da manifestação poética dos sentimentos: "Muito sentimental. / Agora pouco sentimental", e da complexa relação entre poesia e vida: "Autobiografia. Não, biografia" (CESAR, 2013, p. 77). O investimento em uma poesia que reencena incessantemente as ambivalências e tensões, recuperando fragmentos muitas vezes descontextualizados da experiência - em especial da experiência da poeta com a própria literatura - e dispondo tudo isso em um discurso marcado por constantes quebras sintáticas e surpreendentes aproximações lexicais transfere em grande medida para o leitor a tarefa de construir algo a partir de tudo aquilo. Tais procedimentos correspondem à visão da autora de que a poesia se oferece como significante ao leitor, como materialidade à espera do sentido, que se realizará em função da multiplicidade de fios puxados pelo leitor. É nesse aspecto que Ana C. se oporá à ideia da leitura como decifração das entrelinhas: "Eu acho que, no meu texto e acho que em poesia, em geral, não existe entrelinha. Não acho que exista isso de entrelinha. Entrelinha é uma mistificação. Existe linha mesmo, o verso mesmo" (CESAR, 2016, p. 299). Diante do texto reduzido a sua própria materialidade, do poema do qual o poeta se retira cabralinamente "como quem lava as mãos", cabe ao leitor

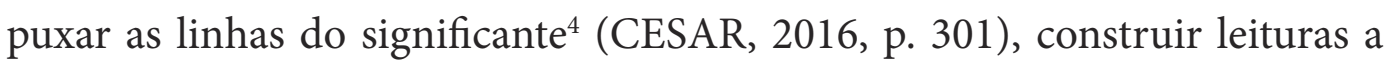
partir do corpo linguístico do poema.

A esta altura já deve estar claro que o diálogo de Ana Cristina Cesar com o legado de João Cabral de Melo de Neto está longe de se resumir à simples e taxativa negação. Se sua geração é "anticabralina por excelência", esse não parece ser seu próprio caso. Refletindo sobre o tema em ensaio recente, Marcos Siscar (2016, p. 109) observa que "A teoria da poesia de Ana C. não difere essencialmente da de Cabral, no ponto específico da superação da relação ingênua entre linguagem e realidade”. A diferença entre os dois projetos parece residir mesmo na reconfiguração do sujeito em sua relação com o outro - em suas diversas faces, conforme procurei mostrar no início deste artigo. Enquanto o esforço de Cabral se orienta na direção de uma linguagem partilhável com e pela coletividade, Ana C. se coloca a tarefa de interromper esse processo de comunicação deixando a cargo do leitor a produção do

\footnotetext{
4 Eis o trecho que tenho em mente, extraído do mesmo depoimento que venho citando: "Não, não é entrelinha isso. Acho que isso é puxar o significante, é diferente. A entrelinha quer dizer: tem aqui escrito uma coisa, tem aqui escrito outra, e o autor está insinuando uma terceira. Não tem insinuação nenhuma, não. Fala em pato, você puxa as associações que você quiser com aquilo. Eu posso lembrar de várias, mas não vou chegar nunca na verdade do meu texto. Não vou dizer nunca para você que, para mim, o símbolo pato significa... Dá pra você puxar. Então, acho que devo puxar. Eu puxo. Agora nessa conversa, nesse pacto aqui nosso, eu puxei que a gente pode cair que nem um patinho na armadilha da intimidade, achar que estou revelando minha intimidade ou escondendo minha intimidade e não é isso, sabe? Podemos puxar outros. Ler é meio puxar fios, e não decifrar" (CESAR, 2016, p. 301).
} 
E. H. N. VERAS Ana Cristina Cesar, Paulo Henriques Britto e o legado de João Cabral sentido, a construção de um segundo discurso a partir do material poético - do corpo do poema - com que ele se depara. Trata-se, como bem mostrou Annita Costa Malufe (2015, p. 76), de uma "desmontagem do gênero íntimo" e de sua conversão em energia poética, em um corpo à espera do leitor.

\section{A poesia como corpo estranho}

O período de formação poética de Paulo Henriques Britto atravessa, segundo ele próprio, pelo menos três fases desde os primeiros exercícios poéticos realizados na juventude. Em "Poesia: criação e tradução", espécie de depoimento concedido à revista Ipotesi, Britto (2008, p. 11) conta que sua motivação inicial para a escrita de poemas era uma "necessidade de expressão" que se desdobrava em um esforço de "verbalização" de determinados "sentimentos e impressões". E a esse primeiro momento, segue-se a descoberta de que sua "ideia de escrever poesia como forma de expressão pessoal correspondia a uma visão romântica e ultrapassada de poesia" (BRITTO, 2008, p. 12). Por outro lado, se o "verdadeiro poeta de [seu] tempo era uma espécie de engenheiro", para quem o universo dos sentimentos individuais cede lugar a projetos racionalizados e a uma concepção construtivista do "trabalho poético", Britto logo descobre-se alheio também ao programa do antilirismo, ao que pese sua admiração e dívida para com a figura de João Cabral de Melo Neto:

Mas a negação da subjetividade representava para mim um obstáculo irremovível. Porque se minha poesia tinha um projeto, ele era justamente esse: o que me parecia ser a descoberta e a manifestação (ou, como eu diria hoje, a construção) de uma identidade subjetiva (BRITTO, 2008, p. 12).

Obstáculo irremovível, o eu é uma instância central para a experiência poética de Paulo Henriques Britto, guardada toda sua ambiguidade de "forma exata da sombra difusa" (BRITTO, 1997, p. 83), como se lê em "História Natural", de Trovar Claro [1997] $]^{5}$. Nesse mesmo poema, vemos o poeta afirmar que "Quem fala sou sempre eu a falar / A máscara é de quem a usa", e, sem perder a dimensão auto-irônica que define amplamente sua poética, enfatizar, como nos primórdios de sua experiência literária, a necessidade de auto-expressão:

\section{No entanto, é preciso dizer-se - mesmo}

que a moda agora mande (e a moda manda,

Revista Letras,

Curitiba, UFPR, n. 102, pp. 152-170, jul./dez. 2020 ISSN 2236-0999 (versão eletrônica) 
e muito) acreditar que o eu é o esmo,

o virtual, o quase extinto, o panda

\author{
desgracioso da história do Ocidente, \\ a devorar o alimento cru \\ que já não sabe como digerir
}

(BRITTO, 1997, p. 83).

Em outra ocasião, procurei demonstrar que essa associação entre o eu - a subjetividade - e os universos, não raro submetidos a uma visada irônica, do corpo (não raro, estranho), da animalidade (não raro cômica, desgraciosa, como no caso do panda) aponta para uma interessante retomada crítica da experiência lírica, isto é, para uma possibilidade de reinserção do eu, da subjetividade, do desejo no seio mesmo da tradição (dita) antilírica à qual, como ele próprio admite, pertence Britto ${ }^{6}$. Retomando de maneira mais direta a tese que procurei outrora esboçar, poderia dizer que a poesia de Britto é capaz de relançar a problemática - e a centralidade do eu - sem abrir mão das conquistas da crítica moderna ao lirismo e à poesia. Arriscaria dizer que o retorno do/ao eu em sua poética é, por fim, inseparável da dimensão metapoética que a caracteriza, pois é na dramatização dos limites da própria crítica, do fracasso da própria negação que a subjetividade emerge novamente como instância incontornável mesmo em seu caráter patético, cômico e baixo. Assim, sua poesia realiza uma afirmação contingencial da subjetividade, entendida como "pouco mais que nada", conforme se lê no primeiro poema da série "Biographia literária", de Formas do nada [2012], no qual o poeta se debruça sobre "(...) tudo que [lhe] resta do começo / disso que agora pensa, fala e sente / que pode ser denominado 'eu”' (BRITTO, 2012, p. 29).

Essa crítica da crítica é esboçada já em Mínima lírica [1989], segundo livro do poeta, na forma de "indagações" direcionadas a dois poetas igualmente centrais para a crítica ao lirismo no âmbito da tradição moderna brasileira e para a própria formação literária e intelectual de Britto ${ }^{7}$. Sua primeira “indagação", "Para João Cabral”, toca exatamente na questão do sujeito e da escrita de si:

\author{
Não escrever sobre si, \\ como se fosse pecado \\ olhar-se em qualquer espelho.
}

6 VERAS, Eduardo. "Cálculos nos intestinos da prosa: a poesia como corpo estranho em Paulo Henriques Britto”. In: PINHEIRO, Tiago Guilherme, RIBEIRO, Gustavo Silveira, VERAS, Eduardo H. N. (org.). Poesia contemporânea: reconfigurações do sensível. Belo Horizonte: Quixote + Do Editoras Associadas, 2018.

7 Cf. "I, too, dislike it", depoimento dado por Britto a Augusto Massi, publicado em Artes e ofícios da poesia, 1991. 
E. H. N. Veras

Ana Cristina Cesar,

Paulo Henriques

Britto e o legado de

João Cabral
Não escrever sobre si,

como se fosse onanismo

sentir-se com algum desejo.

Escrever sim sobre coisas

porque só é limpo e real

o mineral e alheio?

Escrever sim sobre coisas

porque elas não se desnudam

nem retribuem o desejo?

(BRITTO, 2013, p. 98).

O que me parece interessante nesse poema é a palavra final dada à própria indagação, gesto que mantém, como de praxe na obra de Britto, a tensão entre as negativas, elegendo a crítica, a suspeição como força motriz de sua poesia ${ }^{8}$. As perguntas lançadas pelo poeta sugerem uma cisão em relação ao modelo, mas não chegam a se configurar, a despeito do aspecto retórico das interrogações, como uma tomada de partido explicitamente oposta. Proponho que se interprete a indagação de Britto mais como um gesto de problematização, do qual emergirá, como venho defendendo, seu lirismo crítico, do que como uma afirmação direta do retorno incólume do sujeito à poesia brasileira. Em outros termos, esse retorno só se dá na dramatização mesma do fracasso do antilirismo pelas vias do esgotamento crítico e do retorno à banalidade, e só poderia engendrar um sujeito fragmentado, cindido e, de certo modo, humilhado.

Já a segunda "indagação", dirigida "para Augusto de Campos", acrescenta outra questão que se tornaria central para a poética de Britto, em especial por sua vizinhança com a questão do sujeito. Nela, o poeta carioca pergunta ao poeta concreto:

\author{
podar o sentido \\ pudor \\ não recitar \\ citar
}

8 No terceiro poema da série "Gramaticais", publicada no livro Tarde [2007], Britto (2007, p. 41) fala sobre "A sedução das negativas - / essas sereias implacáveis / que se interpõem com seu canto / nos estreitos mais navegáveis (...)". Trata-se, a meu ver, de um movimento que coincide com a própria epistemologia da poética de Britto, afeita à radicalização da crítica até seu próprio esgotamento.
Revista Letras,

Curitiba, UFPR, n. 102, pp. 152-170, jul./dez. 2020 ISSN 2236-0999 (versão eletrônica) 
citar apenas:

"nada a dizer"

esta a suprema forma

de escrever?

(BRITTO, 2013, p. 99).

Refiro-me, evidentemente, à preocupação de Britto com o sentido e sua tênue fronteira com o nada, preocupação que ganharia um lugar de destaque em sua poética, principalmente em seus dois últimos livros - Formas do nada [2012] e Nenhum mistério [2018], aos quais voltarei a seguir. Por ora, cumpre dizer que Britto questiona Augusto de Campos quanto à recusa do sentido - da significação como evento particular e contingente, daí sua relação com a subjetividade - em benefício de uma "forma", de uma escritura marcada pela ausência de impressões digitais, de marcas expressivas, pessoais. Como na indagação a Cabral, Britto mantém mais uma vez a tensão interrogativa, que, a meu ver, se apresenta como gesto de origem de uma poesia que se construirá no limiar entre a consciência do nada e o reconhecimento da necessidade de dizer.

Em linhas gerais, o terceiro momento do processo de formação da visão de poesia de Paulo Henriques Britto coincide com sua atual interpretação "construtiva" do fenômeno poético e da própria subjetividade. Na linhagem de Fernando Pessoa, poeta que ocupa, aliás, lugar privilegiado na formação sensível e técnica de Britto, o sujeito poético passa a ser visto como uma espécie de dramatização, uma ficção na qual se entremeiam elementos poéticos e existenciais:

\footnotetext{
Ao contrário do que se tornou comum afirmar no Brasil desde João Cabral de Melo Neto - ou, mais exatamente, desde que se popularizou uma determinada leitura de Cabral - criar uma poética é muito diferente de projetar uma obra de engenharia. O sujeito lírico é um construto, uma ficção elaborada pelo poeta não apenas para escrever poemas, mas para enfrentar certos problemas de sua vida, atendendo a determinadas necessidades emocionais suas. Ele faz parte da construção da personalidade maior do poeta (BRITTO, 2008, p. 14).
}

Essa ideia do sujeito lírico como um "construto" assume grande importância na poética Britto, como tentei sugerir acima. Ela me parece inseparável de uma visada crítica direcionada tanto para a sua própria prática poética, funcionando como um dispositivo metapoético de constante autorrevisão / autoderrisão, quanto para a tradição da poesia moderna 
E. H. N. VERAS Ana Cristina Cesar, Paulo Henriques Britto e o legado de João Cabral ocidental, em geral, e brasileira, em particular. Numa primeira tentativa de resumir o problema, diria que o sujeito lírico em Paulo Henriques Britto coincide com a dramatização do fracasso do projeto antilírico, projeto no qual se confundem, não raro, é importante dizer, vozes da poesia e da crítica de poesia, como no caso exemplar da leitura que se popularizou de Cabral, como Britto tem o cuidado de mostrar. Para compreendê-lo é preciso, portanto, examinar mais de perto o mecanismo do fracasso na obra do poeta carioca.

No poema de abertura de Tarde [2007], Paulo Henriques Britto reencena o dilema da poesia moderna, e que também é o seu, a respeito da subjetividade lírica. $O$ poema também dramatiza a tensão, no plano da forma, entre o discurso teórico, mimetizado por Britto nas três primeiras estrofes, e o discursos poético, representado pela referência final ao poema "Autopsicografia", de Fernando Pessoa. A tensão entre a "necessidade / de exprimir-se uma subjetividade / numa personalíssima voz lírica" e a "consciência crítica / de um sujeito que se inventa e evade, / ao mesmo tempo ressaltando o que há de / falso em si próprio (...)” (BRITTO, 2007, p. 9) coincide, não por acaso, com o mecanismo próprio à poética de Britto fundado na permanente reconstrução autocrítica do sujeito lírico. Se o poeta toma o partido da poesia em detrimento do discurso teórico, ao afirmar que “(...) o Pessoa, / em doze heptassílabos, já disse o / mesmo não, disse mais - muito melhor" (BRITTO, 2007, p. 9.), é porque a poesia se apresenta a ele como um caminho outro - e privilegiado - de acesso ao real. Esse caminho coincide, a meu ver, com a performatividade crítica de sua poesia, isto é, com sua tendência à autodesconstrução no plano mesmo do poema, metapoeticamente representada e dramatizada ao mesmo tempo pelo tema / forma do fracasso.

No segundo poema da série "Balanços", também do livro Tarde [2007], o poeta se pergunta: "Como saber sem tentar? / Como tentar se é tão fácil / conformar-se de saída / com a ideia de fracasso?". Recusar "de saída” "a ideia do fracasso" parece ser uma escolha ética de Britto, "Pois fracassar justifica / o não se ter nem sequer / admitido não querer-se / aquilo que mais se quer" (BRITTO, 2007, p. 15). Coincidindo com a afirmação do desejo, tema correlato ao da "necessidade de autoexpressão" e igualmente disseminado na obra do poeta carioca, a recusa do fracasso como ponto de partida se converte em enfrentamento, em elogio da própria poesia e, mais amplamente, da própria fala, vista por ele como uma saída para o impasse colocado pelo fracasso, como neste trecho do poema "De vulgari eloquentia", de Macau [2003]:

Há uma saída - falar, falar muito.

São as palavras que suportam o mundo, não os ombros. Sem o "porque", o "sim”,
Revista Letras,

Curitiba, UFPR, n. 102, pp. 152-170,

jul./dez. 2020

ISSN 2236-0999

(versão eletrônica) 
todos os ombros afundam juntos.

Basta uma boca aberta (ou um rabisco

num papel) para salvar o universo.

Portanto, meus amigos, eu insisto:

Falem sem parar. Mesmo sem assunto.

(BRITTO, 2003, p. 18).

A ideia da palavra como resistência ao vazio - e ao fracasso - é um problema que ultrapassa o ceticismo linguístico e epistemológico de Britto e seu aparente elogio da intransitividade poética, da fala "sem assunto". Já no poema de abertura de Formas do nada [2012], "Lorem ipsum”, o problema já aparece associado a uma inusitada dimensão existencial:

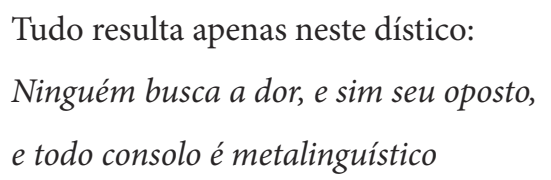

Se a presença do desejo e do corpo como marcas da presença, por sua vez, do sujeito, especialmente nos primeiros livros, já colocava em xeque, de saída, qualquer tentativa de ler o poeta carioca a partir dos pressupostos da tradição autonomista fundada sobre o paradigma da poesia pura, a temática da "dor", do "consolo", do "amor", da "fúria", em suma, a presença de temas existenciais associados direta ou indiretamente à prática da metalinguagem, principalmente nos últimos livros, prova que a obra de Britto é capaz de abrir uma janela para além do enclausuramento da forma vazia. $\mathrm{O}$ "consolo metalinguístico" deve, portanto, ser entendido a partir da associação íntima entre a poesia e a vida, tópico que aponta, desde os primeiros livros de Britto, justamente para o desejo de superação do vazio da forma, como neste trecho do segundo poema da série "Minima poetica”, de Mínima lírica [1989]:

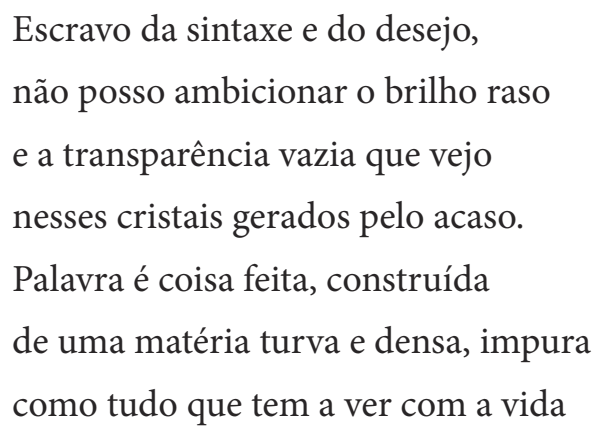


E. H. N. VERAS

Ana Cristina Cesar, Paulo Henriques Britto e o legado de João Cabral

Se a poesia é uma forma de vida entre outras no plano da "biodiversidade", para lembrar o poema de abertura de Macau, penso que à ideia do fracasso, no plano da língua, pode corresponder àquela da decepção, no plano da existência. Em Nenhum mistério [2018], Britto afirma que o "fracasso se tornou / a própria textura da vida" (2018, p. 43) e que a "decepção (...) / é o que há em matéria de sentido” (2018, p. 16). A convergência das dimensões da poesia e da vida - "falar, não por falar, mas pra viver, / falar (ou escrever) como quem respira” (BRITTO, 2013, p. 103), nos versos da parte IV de "Minima poetica" - me permite dizer que, em Britto, ocorre, em última instância, uma convergência entre a "mínima lírica" e a vida mínima, como em "Margem do Douro" (BRITTO, 2018, p. 56): "Não espero nada, e já me satisfaço / com a consciência de ainda estar em mim / e não de volta ao nada de onde vim". Não por acaso, no mesmo poema, é ao plano das sensações que poeta, algo epicurista, se refere nesse momento de satisfação resignada: "permito-me, sem culpa, desfrutar / de pão, e queijo, e vinho, e vista, e ar" (BRITTO, 2018, p. 56). "Escravo da sintaxe e do desejo", o poeta não pode cumprir com excelência a tarefa anfiônica de purificação da palavra, tampouco pode exorcizar de sua língua a dimensão essencialmente corpórea da subjetividade. Em grande medida, para Britto, escrever e viver se conjugam no mesmo tempo.

\section{Carne sutil}

Cada uma à sua maneira, as poéticas de Paulo Henriques Britto e Ana Cristina Cesar respondem criticamente ao legado de Cabral a partir daquilo que eu chamaria de reinvestimento do corpo como instância inseparável da textualidade. Se a linguagem é uma carne sutil que dá corpo ao pensamento do poeta, guardando, entretanto, seu grau de impenetrabilidade, como sugere Collot (2018, p. 51), é possível dizer que ela dá forma e ultrapassa o sujeito ao mesmo tempo, apontando paradoxalmente tanto para o que há de irredutível quanto para o que há de compartilhável em sua própria dimensão corporal. Tanto em Ana C. quanto em Britto, a textualidade é atravessada por essa instância corporal - orgânica, desejante - em grande medida infensa aos esforços de racionalização do discurso poético. Ambos incorporam poeticamente o acaso do corpo, sem, contudo, abrir mão do rigor construtivo e da tarefa comunitária da poesia.

Ana Cristina Cesar (2016, p. 301) afirmou certa vez que "toda mulher comunica com o corpo". Interessa-me sobretudo nessa frase o reconhecimento de que a vida e o texto estabelecem em muitos aspectos uma relação de reversibilidade: "Enquanto leio meus seios estão a descoberto. É 
difícil concentrar-me ao ver seus bicos. Então rabisco as folhas deste álbum. Poética quebrada pelo meio" (CESAR, 2013, p. 206). É justamente esse texto atravessado pelo corpo - pelo acaso do desejo e da organicidade - que se oferece como provocação ao leitor: "É para você que escrevo - hipócrita. / Para você - sou eu que te seguro os ombros e grito verdades / nos ouvidos, no último momento. / Me jogo aos teus pés inteiramente grata" (CESAR, 2013, p. 121). O corpo que atravessa o poema acaba por converter-se no corpo do poema, pensado em sua materialidade algo indevassável, como já foi dito. Ana C. propõe a imersão nessa materialidade da língua como zona de impacto entre a teatralização da intimidade e a convocação do leitor, de quem se espera uma reação em forma de leitura, no lance de dados de um fio puxado.

Já em Paulo Henriques Britto, para quem a própria poesia é corpo estranho ${ }^{9}$, cálculos que interrompem o fluxo normal dos intestinos da prosa, como se vê na terceira seção de "Oficina", de Formas do nada (BRITTO, 2012, p. 15), o problema parece se resolver no plano da construção de uma persona poético-crítica que encena a tensão entre a subjetividade (o eu, o corpo, o desejo) e sua negação, entre a adesão a um ideal antipoético e o reconhecimento de seu fracasso, desaguando finalmente numa afirmação ambivalente da palavra impura como suporte da realidade, como realidade possível. Por isso, Britto prefere pensar sua poética nos termos de uma "Fisiologia da composição" que incorpora de maneira ambivalente, numa espécie de adesão autoirônica, "O incômodo pejo / de ser só desejo" e constata que "Por fim, o acaso. / Sem o qual, nada" (BRITTO, 2003, p. 13). Tal incorporação reconfigura mais que renega, a meu ver, um tema fundamental em João Cabral, especialmente a partir de Psicologia da composição, a tarefa comunicativa da poesia, que Britto evocará, no segundo poema da referida série "Fisiologia da composição", como "o múnus / público da coisa". O problema propriamente fisiológico da poesia se explica pela centralidade de um "impulso" profundo, "uma pressão / que vem de dentro, e incomoda" (BRITTO, 2003, p.15), que o poeta ao mesmo tempo que acolhe, rechaça. Como em Ana Cristina Cesar, aqui o legado de João Cabral é reconfigurado em função do retorno de uma subjetividade atravessada pelo corpo, pelo desejo, pelas emoções, mas que não abre mão, por outro lado, do rigor construtivo e da tarefa de se comunicar nessa língua estranha, "outra forma de vida", como diz Britto (2003, p. 9), a que chamamos poesia.

9 Duplamente estranho, é preciso dizer. Invasor, como os cálculos no intestino, em "Oficina", ebizarro, como os "cágados com as quatro patas viradas pro ar", em "Biodiversidade" (BRITTO, 2003, p. 9). 
E. H. N. VERAS Ana Cristina Cesar, Paulo Henriques Britto e o legado de João Cabral

\section{Referências}

BANDEIRA, Manuel. Estrela da vida inteira. 20. ed. Rio de Janeiro: Nova Fronteira, 1993.

BRITTO, Paulo Henriques Britto. “I, too, dislike it”. In: MASSI, Augusto (org.). Artes e ofícios da poesia. Porto Alegre: Artes e ofícios, 1991.

BRITTO, Paulo Henriques Britto. Trovar claro. São Paulo: Companhia das Letras, 1997.

BRITTO, Paulo Henriques. Macau. São Paulo: Companhia das Letras, 2003.

BRITTO, Paulo Henriques. Tarde. São Paulo: Companhia das Letras, 2007.

BRITTO, Paulo Henriques Britto. Poesia: criação e tradução. Ipotesi. Volume 12, n. 2, p. $11-17$, jul./dez. 2008.

BRITTO, Paulo Henriques. Formas do nada. São Paulo: Companhia das Letras, 2012.

BRITTO, Paulo Henriques. Mínima lírica. 2. ed. São Paulo: Companhia das Letras, 2013.

BRITTO, Paulo Henriques. Nenhum mistério. São Paulo: Companhia das

CABRAL DE MELO NETO, João. Obra completa. Rio de Janeiro: Nova Aguilar, 1994.

CAMPOS, Haroldo de. Poesia de modernidade: da morte da arte à constelação. O poema pós-utópico. In: O arco-íris branco. Rio de Janeiro: Imago, 1997.

CESAR, Ana Cristina. Poética. São Paulo: Companhia das Letras, 2013.

CESAR, Ana Cristina. Crítica e tradução. São Paulo: Companhia das Letras, 2016.

COSTA LIMA, Luiz. Lira e antilira. Mário, Drummond, Cabral. 2. ed. revista. Rio de Janeiro: Topbooks, 1995.

COLLOT, Michel. A matéria-emoção. Trad. Patrícia Souza Silva. Rio de 
Janeiro: Oficina Raquel, 2018.

FRIEDRICH, Hugo. Estrutura da lírica moderna: da metade do século XIX a meados do século XX. Trad. Marise M. Curioni. São Paulo: Duas Cidades, 1978.

GANDOLFI, Leonardo. João Cabral vê seu rosto no desenho do mundo. In: DICK, André (org.). Paideuma. São Paulo: Risco Editorial, 2010.

JANKÉLÉVTCH, Vladimir. A música e o inefável. Trad. Clóvis Salgado Gontijo. São Paulo: Perspectiva, 2018

MALUFE, Annita Costa. "Estratégias para uma escrita do segredo". In: FALEIROS, Álvaro; ZULAR, Roberto; BOSI, Viviana. Sereia de papel: visões de Ana Cristina Cesar. Rio de Janeiro: EdUERJ, 2015.

MAULPOIX, Jean-Michel. La poésie comme lamour. Essai sur la relation lyrique. Paris: Mercure de France, 1998.

SISCAR, Marcos. A cisma da poesia brasileira. In: Poesia e crise: ensaios sobre a "crise da poesia" como topos da modernidade. Campinas: Editora da Unicamp, 2010.

SISCAR, Marcos. Ana C. aos pés da letra. In: De volta ao fim: o "fim das vanguardas" como questão da poesia contemporânea. Rio de Janeiro: 7Letras, 2016.

SISCAR, Marcos. João Cabral e a poesia contemporânea: o drama da destinação. Texto poético. volume 14, n. 25, p. 610-616, jul./dez. 2018.

VERAS, Eduardo. Cálculos nos intestinos da prosa: a poesia como corpo estranho em Paulo Henriques Britto. In: PINHEIRO, Tiago Guilherme, RIBEIRO; Gustavo Silveira, VERAS; Eduardo H. N. (org.). Poesia contemporânea: reconfigurações do sensível. Belo Horizonte: Quixote + Do Editoras Associadas, 2018.

Submetido em: 17/09/2020

Aceito em: 31/10/2020 